\title{
Dietary Assessment of SHG (Self Help Group) Rural Households of Mahboobnagar District, Telangana, India
}

\author{
J. Shirisha*, K. Uma Devi and S. Suchiritha Devi \\ Department of Foods and Nutrition, College of Home Science, Professor Jayashankar Telangana \\ State Agricultural University, Hyderabad- 500004, Telangana, India \\ *Corresponding author
}

\author{
A B S T R A C T
}

\begin{tabular}{|l|}
\hline Ke y w o r d s \\
SHGs, Non SHG, \\
Micro finance, \\
Income, Consumption, \\
Dietary assessment, \\
CU (Consumption \\
Unit). \\
\hline Article Info \\
\hline $\begin{array}{l}\text { Accepted: } \\
\text { 23 September } 2017 \\
\text { Available Online: } \\
\text { 10 October } 2017\end{array}$ \\
\hline
\end{tabular}

Dietary assessment is the process of evaluating what people eat by using one or several intake indicators. It is the best approach for identifying nutrients that are likely to either be under-or over consumed by the individual or groups of interest. It also can be used to identify food patterns and preferences. Dietary assessment was done through food weighment and dietary diversity to identify the food consumption pattern, food and nutrients intake and food preferences of SHG and Non SHG households. This study was conducted on 120 SHG households and 30 Non SHG households. The primary data was collected from the women. Based on the consumption of food groups data is understood that the diets are having inadequate sources of protein as the pulse, milk and meat intake was found to be less. Similarly the micronutrient intake would have been less due to lack of fruit intake and meager intake of green leafy vegetables. Adequate cereal and sugar intake and a higher intake of fats and oils is indicative of calorie fulfillment per CU (Consumption Unit) in both SHG and Non SHGs. In general comparison of intake of each of the food groups per consumption unit did not show any significant difference between SHG and Non SHG. Though the mean food intake values of individual groups showed mild to moderate differences, the SD values seem to have nullified the difference.

\section{Introduction}

Women constitute a major part of beneficiaries of micro-finance activities in India. It helps women to gain control over the means of living and lift themselves out of poverty and vulnerability. By saving one rupee per day per head they themselves evolve as the driving force and borrow from their savings and invest in their family with the income they generate through this microfinance. It helps women to achieve economic and political empowerment within their homes, their villages and their countries. SHGs have an in-built mechanism where emphasis has been given over capacity building of women through developing their dialoguing skills. An SHG functions through its regular meetings, where members perform transactional activities and discuss over different related issues. This discussion among the group members is the means through which they give voice to their needs and it proves to be a platform for addressing their social and economic problems and enlightening their inner selves as well. The SHGs provide economic benefits in certain areas of production process by undertaking 
common action programmes, like costeffective credit delivery system, generating a forum collectively, learning with rural people, promoting democratic culture, fostering an entrepreneurial culture, providing a firm base for dialogue and cooperation in programmes with other institutions, possessing credibility and power to ensure participation and helping to assess an individual member's management capacity. SHGs enhance the equality of status of women as participants, decision-makers and beneficiaries in the democratic, economic, social and cultural spheres of life. They have inculcated a great confidence in the minds of rural women to succeed in their day to day life (Ritu et al., 2003). Program had three main impacts: increases in social capital and economic empowerment, nutritional improvement (despite persistent drought at the time), and an increase in consumption for participants of new groups. The findings did not, however, find increases in income or assets, but interestingly, the effects were not limited to group members, indicating spill-over effects for communities in which SHGs were formed (Deininger and Liu, 2009).

Food security of members of households has improved after participation in SHGs. Acute malnutrition among children, infant and child mortality / premature adult deaths have comparatively declined (Joy DeshmukhRanadive 2004).

\section{Materials and Methods}

The study was an attempt to assess the SHGs impact on dietary intake. The survey was carried out in the villages of Aurepalli and Dokuru villages of Mahaboobnagar. Sixty SHG households and 15 Non SHG controls were selected from each of the village.Dietary assessment is the process of evaluating what people eat by using one or several intake indicators. Dietary assessment was done through food weighment and dietary diversity to identify the food consumption pattern, food and nutrients intake and food preferences of SHG and Non SHG households.

\section{Results and Discussion}

To measure dietary diversity, household food access to a variety of foods was obtained through the data on food consumption frequency collected using a structured questionnaire and daily consumed food groups were given a score of ' 1 ' each and not consumed daily were scored ' 0 '. The pooled data of foods consumed daily is given in table 1 for both SHG and Non-SHG families.

Dietary diversity was assessed by inclusion of foods from different food groups indicate that cent percent of SHG and Non-SHGs consumed cereals, sugars and cooking oil. Nearly $83 \%$ both SHGs and Non SHG had a habit of using milk in the form of tea consumption. Daily pulse consumption was only $15 \%$ of the SHG and only $3 \%$ of NonSHG households. As per the vegetables are concerned both SHG nor Non-SHG families had very poor intake 8 and $7 \%$ of green leafy vegetables, $36 \%$ of SHGs and $27 \%$ of NonSHGs consumed other vegetables which was also less to moderate. Four percent of SHGs had the habit of regular consumption of fruits which was poor and no intake was reported among Non SHG. While 1\% of SHGs and 3\% Non-SHGs eat at least any one non vegetarian food like chicken, meat, egg or fish on a regular basis, majority of both the groups did not consume this food group daily.

The household practices of including foods from the nine food groups, cereals, pulses, vegetable-A, vegetable-B, fruits, milk and milk products, meat and meat products, fats and oils and sugars provided valuable information on the dietary diversity of households. It was observed that mostly five 
food groups namely cereals, vegetable-B, milk products, oils and sugars were being consumed by the majority of SHG and NonSHGs. from the food groups consumed, it is clear that the households were consuming nutritionally imbalanced food, providing carbohydrate and fat calories mostly, and deficient in protein both in terms of quality and quantity and the possibility of micronutrient deficiency cannot be ignored due less or no frequent intake of pulses, leafy vegetables, fruits and meat products.

It is observed from the above table both the SHG and NONSHG households are not meeting the RDA for energy and protein where opposite to the fat. The results were found to be rejecting the results of Deininger and Liu (2009) that SHGs helped to improve food consumption and nutritional status of the poor. Despite of a decline in food and nutrient intake an improved nutritional status noticed due to non-nutritional factors such as improvement in access to safe drinking water, better out-reach of health care services coupled with improvement in socio-economic conditions (NNMB, 2006).

The food consumed for the day was obtained through food weighment and calculated nutrient are compared against RDA and given in table 2.

In the respective order of $\mathrm{SHG}$ and Non SHGs, the intake of different foods per consumption unit(CU) was $414 \pm 80 \mathrm{gms}$ and $413 \pm 83$ gms from cereals, $35 \pm 37$ gms and $27 \pm 26$ gms from pulses, $27 \pm 11$ gms and 29 \pm 20 from fats and oils, $10 \pm 26 \mathrm{gms}$ and $6 \pm$ 12 from green leafy vegetables (veg-A), $130 \pm$ 74 gms and $166 \pm 114$ from other vegetables (veg-B), $68 \pm 82$ gms and $87 \pm 57$ from milk and milk products, $26 \pm 54$ gms and $26 \pm 75$ from meat products and 18 and 9 gms from sugars. No fruit consumption was recorded in the SHG, while $65 \pm 205$ gms of fruit was consumed by Non SHGs. No significant difference $(\mathrm{P}<0.01)$ was found both among SHG and Non SHG in consumption of all the nine food groups.

Table.1 Food groups included in the dietaries of SHG and Non-SHG Households

\begin{tabular}{|c|c|c|c|c|c|c|}
\hline \multirow[t]{2}{*}{ S.NO } & \multirow[t]{2}{*}{ Food Groups } & \multirow[t]{2}{*}{ Food Items } & \multicolumn{2}{|c|}{ SHG(120) } & \multicolumn{2}{|c|}{ Non SHG(30) } \\
\hline & & & Yes=1 & $\mathrm{NO}=2$ & Yes=1 & $\mathrm{NO}=2$ \\
\hline 1 & Cereals & $\begin{array}{l}\text { Rice, wheat, sorghum and } \\
\text { other millets }\end{array}$ & $100(120)$ & - & $100(30)$ & - \\
\hline 2 & Pulses & $\begin{array}{l}\text { Redgramdal, Bengalgramdal, } \\
\text { Blackgramdal etc. }\end{array}$ & $15(18)$ & $85(102)$ & $3(1)$ & $97(29)$ \\
\hline 3 & Vegetable-A & $\begin{array}{l}\text { Amaranth, Spinach, Gogu, } \\
\text { Curry leaves etc... }\end{array}$ & $8(10)$ & $92(110)$ & $7(2)$ & $93(28)$ \\
\hline 4 & Vegetable -B & Gourds, Beans, Tubers & $36(43)$ & $64(77)$ & $27(8)$ & $72(22)$ \\
\hline 5 & Fruits & $\begin{array}{l}\text { Apple, Grapes, Banana, } \\
\text { Orange etc. }\end{array}$ & $4(5)$ & $96(115)$ & - & $100(30)$ \\
\hline 6 & $\begin{array}{l}\text { Milk and Milk } \\
\text { products }\end{array}$ & $\begin{array}{l}\text { Cow milk, Buffalo milk, } \\
\text { Curd etc. }\end{array}$ & $83(99)$ & $17(21)$ & $83(25)$ & $17(5)$ \\
\hline 7 & $\begin{array}{l}\text { Meat and meat } \\
\text { products }\end{array}$ & Chicken, Mutton, Egg, Fish & $1(1)$ & $99(119)$ & $3(1)$ & $97(29)$ \\
\hline 8 & Fats and Oils & $\begin{array}{l}\text { Groundnut, Palm oil, } \\
\text { Sunflower etc. }\end{array}$ & $100(120)$ & - & $100(30)$ & - \\
\hline 9 & Sugars & Sugar, Jaggery & $97(116)$ & $3(4)$ & $100(30)$ & - \\
\hline
\end{tabular}

Figures in the parenthesis indicate number of households 
Table.2 Consumption of food groups of SHG and NONSHG households per consumption unit (CU)

\begin{tabular}{|l|l|l|l|l|l|}
\hline S.NO & Food groups $($ gms $)$ & SHG & NON SHG & P-value & RDA*(gms) \\
\hline 1. & Cereals & $413.5 \pm 80.28$ & $412.6 \pm 83.48$ & 0.48 & 420 \\
\hline 2. & Pulses & $34.91 \pm 37.28$ & $26.83 \pm 26.2$ & 0.24 & 60 \\
\hline 3. & Fats and oils & $26.88 \pm 11.45$ & $28.74 \pm 19.90$ & 0.43 & 20 \\
\hline 4. & Veg-A & $10.04 \pm 26.42$ & $5.54 \pm 11.70$ & 0.26 & 100 \\
\hline 5. & Veg-B & $129.66 \pm 74.24$ & $155.54 \pm 114.33$ & 0.26 & 100 \\
\hline 6. & Milk \& milk products & $65.73 \pm 81.76$ & $87.26 \pm 57.26$ & 0.17 & 300 \\
\hline 7. & Meat \&meat products & $26.44 \pm 54.25$ & $25.96 \pm 75.13$ & 0.49 & 100 \\
\hline 8. & Fruits & 0 & $64.9 \pm 205.2$ & 0.17 & 100 \\
\hline 9. & Sugars & $18.42 \pm 8.97$ & $20.42 \pm 8.81$ & 0.28 & 25 \\
\hline
\end{tabular}

Significant Level-- P-value-P<0.01 Non-significant

Source: Dietary guidelines for Indians- A manual, 1999, NIN, ICMR, Hyderabad.

Table.3 Nutrient intake of SHG and NONSHG households per consumption unit (CU)

\begin{tabular}{|l|l|l|l|l|l|}
\hline \multirow{2}{*}{ Nutrients } & \multicolumn{2}{|c|}{ SHG(n=20) } & \multicolumn{2}{c|}{ NONSHG(n=10) } & \multirow{2}{*}{ P value } \\
\cline { 2 - 5 } & Mean \pm SD & \% Adequacy & Mean \pm SD & $\%$ Adequacy & \\
\hline Energy $(\mathrm{kcal})$ & $2028.33 \pm 308.83$ & $87.37 \pm 13.02$ & $2109.5 \pm 386.93$ & $90.89 \pm 16.70$ & 0.28 \\
\hline Protein $(\mathrm{gm})$ & $49.38 \pm 17.29$ & $82.26 \pm 28.81$ & $48.35 \pm 21.06$ & $80.55 \pm 35.11$ & 0.44 \\
\hline Fat $(\mathrm{gm})$ & $33.60 \pm 11.38$ & $137.41 \pm 45.48$ & $40.9 \pm 26.98$ & $163.58 \pm 107.94$ & 0.21 \\
\hline
\end{tabular}

Significant Level-- P-value-P $<0.01$ Non-significant

When the consumption of foods was compared with recommended food allowances of ICMR, it was observed that cereal consumption of both SHG and Non SHG was almost close to requirement, but the mean pulse consumption was found to be 25 to $33 \mathrm{gms}$ less than the requirement in SHG and Non SHG respectively. The fat consumption was greater than the requirement by 7 to $9 \mathrm{gms}$ in SHG and Non SHG respectively. Green leafy vegetable intake was very low in both the groups by nearly 90 to 94 gms against a requirement of 100 gms. Intake of roots and other vegetables was found to be more than the requirement in both the groups, where Non SHG consumed more than SHG. The milk intake was meeting $1 / 4$ th of the requirement of $300 \mathrm{gms}$ in both the groups. Consumption of meat and meat products was also found to be meeting 1/4th of the requirement. Fruit intake was nil in SHG and Non SHG on the day of weighment except for one family of Non SHG. Sugar intake was moderately good, less only by 5 to $7 \mathrm{gms}$ compared to the requirement. Low intake of different food items was related to poor economic status (Venkateswaralu, 2003).

Based on the consumption of food groups data is understood that the diets are having inadequate sources of protein as the pulse, milk and meat intake was found to be less. Similarly the micronutrient intake would have been less due to lack of fruit intake and meager intake of green leafy vegetables. Adequate cereal and sugar intake and a higher intake of fats and oils is indicative of calorie fulfillment per $\mathrm{CU}$ in both SHG and Non SHGs. NNMB, 2012 reported the decreasing trend in the intakes of roots and tubers $(6 \mathrm{~g})$ milk \& milk products $(21 \mathrm{ml})$, sugar and jaggery $(9 \mathrm{~g})$ and other vegetables $(6 \mathrm{~g})$. However, a marginal increase was also observed in the intakes of GLVs $(8 \mathrm{~g})$, and fats and oils $(2 \mathrm{~g})$.

In general comparison of intake of each of the food groups per consumption unit did not show 
any significant difference between SHG and Non SHG. Though the mean food intake values of individual groups showed mild to moderate differences, the SD values seem to have nullified the difference. The mean energy intake of SHG and Non SHGs per consumption unit was $2028 \pm 309$ and $2110 \pm 387 \mathrm{k}$ cal respectively. The protein intake of both the groups was almost same with $49 \pm 17$ and $48 \pm 21$ gms in SHG and Non SHGs. The fat intake per CU was $34 \pm 11 \mathrm{gms}$ in SHG and $41 \pm 27 \mathrm{gms}$ in Non SHGs given in table 3.

The mean intake of each nutrient when compared against the recommended dietary allowances (RDA) of ICMR revealed that the percent adequacy of energy was $87 \% \pm 13 \%$ in SHG and $91 \% \pm 17 \%$ in Non SHG indicating a gap of 9 to $13 \%$ deficit and that the percent deficit was more in SHG compared to Non SHG. But no significant difference was found between SHG and Non SHGs $(\mathrm{P}<0.01)$. The protein content of the diet consumed was also less than the requirement and met only $82 \% \pm$ $29 \%$ and $81 \% \pm 35 \%$ of the requirement in the SHG and Non SHGs respectively without any significant difference $(\mathrm{P}<0.01)$ between the groups. Percent adequacy of fat was high with $137 \%$ and $164 \%$ in SHG and Non SHGs respectively compared to the RDA and no significant difference $(\mathrm{P}<0.01)$ was found between the groups.

The survey during different time points also observed decrease in the intake of energy and proteins over the periods, while that of fat intake has increased during the same period. Similar results were found that the intake of all the nutrients declined over a period of 4 decades. The intake of protein has declined by $13 \mathrm{~g} / \mathrm{CU} /$ day over a period of time (NNMB, 2012). From the food intake and nutrient adequacy data it can be inferred that Self Help
Grouping has not influenced neither the food intake in terms of dietary diversity, quantity of foods consumed from different food groups nor the nutrient adequacy. Policy-makers and programme implementers must act today to free the nation from double burden of nutrition and plan to create nutrition-sensitive interventions that will increase impact and improve health of the population.

\section{References}

Joy Deshmukh-Ranadive. 2004. Women's SelfHelp Groups in Andhra PradeshParticipatory Poverty Alleviation in Action. Proceedings of the conference on "Scaling up Poverty Reduction: A Global Learning Process Shanghai, May 25 - 27.

Klaus Deininger and Liu Y.2009.Policy research working paper on Economic and Social Impacts of Self-Help Groups in India. The World Bank publications.

National Nutrition Monitoring Bureau. 2006. Diet and Nutritional status of rural Population (2005-06). National Institute of Nutrition, Indian Council of Medical Research, Hyderabad.

National Nutrition Monitoring Bureau. 2012. Diet and Nutritional status of rural population, prevalence of hypertension and diabetes among adults and infants and young child feeding practices- report of third repeat survey. National Institute of Nutrition, Indian Council of Medical Research, Hyderabad.

Ritu J, Kushawaha R.K and Srivastava A.K. 2003. Socio- Economic impact through self-help groups, Yojana.47(7), 11-12.

Venkateshwarlu, V. 2003. Health status of the rural aged in Andhra Pradesh- A social perspective. Indian Research and Development Journal. 9(2): 17.

\section{How to cite this article:}

Shirisha, J., K. Uma Devi and Suchiritha Devi, S. 2017. Dietary Assessment of SHG (Self Help Group) Rural Households of Mahboobnagar District, Telangana, India. Int.J.Curr.Microbiol.App.Sci. 6(10): 2848-2852. doi: https://doi.org/10.20546/ijcmas.2017.610.334 